\title{
Curcumin improves the efficacy of cisplatin by targeting cancer stem-like cells through p21 and cyclin D1-mediated tumour cell inhibition in non-small cell lung cancer cell lines
}

\author{
PUTERI BAHARUDDIN ${ }^{1 *}$, NAZILAH SATAR ${ }^{2 *}$, KAMAL SHAIK FAKIRUDDIN $^{1}$, NORASHIKIN ZAKARIA ${ }^{2}$, \\ MOON NIAN LIM ${ }^{1}$, NARAZAH MOHD YUSOFF ${ }^{2}$, ZUBAIDAH ZAKARIA ${ }^{1}$ and BADRUL HISHAM YAHAYA ${ }^{2}$ \\ ${ }^{1}$ Stem Cell Laboratory, Haematology Unit, Cancer Research Centre, Institute for Medical Research (IMR), \\ Jalan Pahang, Kuala Lumpur 50588; ${ }^{2}$ Regenerative Medicine Cluster, Advanced Medical and Dental \\ Institute (AMDI), University Sains Malaysia, Kepala Batas, Penang 13200, Malaysia
}

Received July 2, 2015; Accepted August 18, 2015

DOI: $10.3892 / o r .2015 .4371$

\begin{abstract}
Natural compounds such as curcumin have the ability to enhance the therapeutic effectiveness of common chemotherapy agents through cancer stem-like cell (CSC) sensitisation. In the present study, we showed that curcumin enhanced the sensitivity of the double-positive $\left(\mathrm{CD} 166^{+} / \mathrm{EpCAM}^{+}\right) \mathrm{CSC}$ subpopulation in non-small cell lung cancer (NSCLC) cell lines (A549 and H2170) to cisplatin-induced apoptosis and inhibition of metastasis. Our results revealed that initial exposure of NSCLC cell lines to curcumin (10-40 $\mu \mathrm{M})$ markedly reduced the percentage of viability to an average of $\sim 51$ and $\sim 54 \%$ compared to treatment with low dose cisplatin $(3 \mu \mathrm{M})$ with only 94 and $86 \%$ in both the A549 and H2170 cells. Moreover, sensitisation of NSCLC cell lines to curcumin through combined treatment enhanced the single effect induced by low dose cisplatin on the apoptosis of the double-positive CSC subpopulation by 18 and $20 \%$ in the A549 and H2170 cells, respectively. Furthermore, we found that curcumin enhanced the inhibitory effects of cisplatin on the highly migratory $\mathrm{CD} 166^{+} / \mathrm{EpCAM}^{+}$subpopulation, marked by a reduction in cell migration to 9 and $21 \%$ in the A549 and $\mathrm{H} 2170$ cells, respectively, indicating that curcumin may increase the sensitivity of CSCs to cisplatin-induced migratory inhibition. We also observed that the mRNA expression of cyclin D1 was downregulated, while a substantial increased in 21 expression was noted, followed by Apaf1 and caspase-9 activation in the double-positive $\left(\mathrm{CD}_{166} / \mathrm{EpCAM}^{+}\right) \mathrm{CSC}$ subpopulation of A549 cells, suggested that the combined
\end{abstract}

Correspondence to: Dr Puteri Baharuddin, Stem Cell Laboratory, Haematology Unit, Cancer Research Centre, Institute for Medical Research (IMR), Jalan Pahang, Kuala Lumpur 50588, Malaysia E-mail: puteri@imr.gov.my

${ }^{*}$ Contributed equally

Key words: curcumin, cisplatin, cancer stem-like cells, non-small cell lung cancer treatments induced cell cycle arrest, therefore triggering CSC growth inhibition via the intrinsic apoptotic pathway. In conclusion, we provided novel evidence of the previously unknown therapeutic effects of curcumin, either alone or in combination with cisplatin on the inhibition of the $\mathrm{CD} 166^{+} / \mathrm{EpCAM}^{+}$ subpopulation of NSCLC cell lines. This finding demonstrated the potential therapeutic approach of using curcumin that may enhance the effects of cisplatin by targeting the CSC subpopulation in NSCLC.

\section{Introduction}

Lung cancer is the second leading cause of cancer-related mortality worldwide, and more than 1.6 million cases are diagnosed every year (1). Tobacco smoking and exposure to environmental carcinogens have been found to be the major risk factors in the development of this disease (2). Most lung cancer patients are diagnosed in an advance stage with an overall survival of five years (1). Despite considerable advances in our knowledge and experience in the treatment of lung cancer patients, our capacity to effectively fight and treat this disease is still limited (3). Treatment of lung cancer patients only manages to reduce the burden of the primary lesion but rarely is effective to completely eradicate the tumour cells which in turn leads to relapse and fatality (2). These facts and limitations highlight the need for the greater understanding of the cellular and molecular events that drive tumourigenesis. Thus, therapeutic strategies can be tailored for better treatment efficacies.

Lung cancer can be classically subdivided into small cell lung cancer (SCLC) and three types of non-small cell lung cancer (NSCLC), which include squamous cell carcinoma, adenocarcinoma and large cell carcinoma (4). The existence of several lung epithelial progenitor cells that initiate diverse lung epithelial subtypes and functions is thought to be responsible for this tumour variety (5). The cancer stem cell (CSC) theory suggests that mutations in the progenitor cells lead to the formation of CSCs resulting in cellular hierarchy and clonal expansion within a tumour $(6,7)$. CSCs are known to share common properties with normal epithelial stem cells 
including self-renewal, proliferation and capacity for lineage differentiation $(6,8,9)$. However, CSCs may not necessarily be homogeneous in general as they often evolve subsequently by accumulating additional mutations, which in turn results in a complex clonal heterogeneity (10). CSCs are also believed to be the driving source of the malignant phenotype (resistance to chemotherapy, distant metastasis and relapse) in the primary tumour (11). Therefore, therapies that target chemoresistant tumour cells and distant tumour metastasis, which are characteristic of CSCs, may be an effective and yet powerful treatment strategy to eradicate the primary tumour $(12,13)$.

Curcumin (diferuloymethane), a naturally occurring polyphenol extract from the rhizome Curcuma longa (Tumeric), possesses biological activities against many types of tumours (14-18). Curcumin modulates numerous target proteins including transcription factors, receptors, kinases, cytokines, enzymes and growth factors (19). Curcumin was found to downregulate the expression of several drug-resistance proteins such as ATP-binding cassette (ABC) drug transporters, P-glycoproteins and multi-drug resistant (MDR) proteins, which resulted in the sensitivity of tumour cells to chemotherapy (20-22). Pre-clinical studies have shown that curcumin acts synergistically with conventional chemotherapeutic drugs to eradicate resistant lung cancer cell lines $(20,23,24)$. Similar findings with different tumours have also been reported in vitro as well as in experimental animal models (25-28). In a human breast cancer xenograft model, administration of curcumin markedly decreased the metastasis of breast tumour cells to the lung and suppressed the expression of vascular endothelial growth factor (VEGF), matrix metalloproteinase-9 (MMP-9) and intercellular adhesion molecule-1, which reduced the invasive and metastatic phenotype of the tumour cells (29). Furthermore, curcumin has been found to be safe when administered at $\leq 10 \mathrm{~g} /$ day in humans, thus reducing the difficulty of reaching an effective dose due to dose-limiting toxicity (30).

The antitumour efficacy of curcumin has also been studied recently, either alone or in combination with other antitumour agents on stem-like cells isolated from several tumours using in vitro CSC assays (sphere formation, enzyme activity, side population and cell-surface marker expression) as well as in vivo animal models. In breast cancer models, $5 \mu \mathrm{M}$ of curcumin treatment reduced mammosphere formation by $50 \%$, while complete elimination of mammospheres and reduction in aldehyde dehydrogenase 1 (ALDH) enzyme activity (a selective marker noted in most CSCs) were noted as the concentration of curcumin was increased to $10 \mu \mathrm{M}(31,32)$. A study conducted by Fong et al using an in vivo glioma model reported that daily treatment of $5 \mu \mathrm{M}$ curcumin resulted in the reduction of the side population as analysed by flow cytometry (33). Furthermore, curcumin also reduced the expression of CD133 and nestin (neural stem/progenitor markers) indicating the differentiation of gliomal CSCs that eventually led to deregulation of the self-renewal capability of CSCs (34).

CD133 was recently reported as a promising CSC marker noted in prostate cancer (35-37), brain tumours (38-41), colon cancer (42-44) and hepatic carcinoma (45-48). However, in the context of lung cancer stem cells, the utility of the marker appears limited due to the low expression detected in most lung cancer samples $(49,50)$, and the discrepancy of the find- ings in regards to CD133 in most studies have questioned the prognostic value of this marker in clinical application (50-52). It is therefore important to identify markers that are commonly expressed in most lung cancer samples; hence it can be applied in a larger fraction of lung tumour samples. Other studies established that CSC markers such as CD326 (EpCAM) and CD166 are more robust compared to CD133 as these markers are highly detected in most NSCLC cancer samples $(53,54)$. Furthermore, $\mathrm{CD} 166^{+} / \mathrm{Lin}^{-}$markers were also found to be prominent in NSCLC patients suggesting the applicability of CD166 as a selective marker for CSCs in NSCLC (54). We previously identified and characterised, based on in vivo tumourigenicity, a novel $\mathrm{CD}_{166} / \mathrm{EpCAM}^{+} \mathrm{CSC}$ subpopulation isolated from NSCLC cell lines, and showed that this subpopulation has self-renewal capacity, higher mobility, resistance to apoptosis and exhibits mesenchymal lineage differentiation based on gene expression profiling (55). In the present study, we investigated the anticancer effects of curcumin (either alone or in combination with cisplatin) as a drug sensitiser and metastatic inhibitor on both unsorted and sorted (CD166 and EpCAM) cancer stem-like populations derived from NSCLC cell lines. This study will provide further insight into the potential of using curcumin as a sensitiser of CSCs to cisplatin-induced cell death.

\section{Materials and methods}

All of the cell lines were purchased from the American Type Culture Collection (ATCC, Manassas, VA, USA). The research protocol was approved by our Institutional Review Boards (Medical Research Ethics Committee/MREC, Ministry of Health, Malaysia).

Cell culture. NSCLC cell lines, A549 (ATCC ${ }^{\circledR}$ CRL-185 ${ }^{\mathrm{TM}}$ ) and $\mathrm{H} 2170$ (ATCC ${ }^{\circledR}$ CRL-5928 ${ }^{\mathrm{TM}}$ ) were cultured in RPMI-1640 (Invitrogen, Carlsbad, CA, USA) medium containing $10 \%$ fetal bovine serum (FBS), $100 \mathrm{IU} / \mathrm{ml}$ penicillin and $100 \mu \mathrm{g} / \mathrm{ml}$ streptomycin (all purchased from ATCC) and grown at $37^{\circ} \mathrm{C}$ in a humidified $5 \% \mathrm{CO}_{2}$ atmosphere. Human lung fibroblast (IMR-90) cells were cultured in MEM- $\alpha$ (1x)-Glutamax medium containing 10\% FBS, $100 \mathrm{IU} / \mathrm{ml}$ penicillin and $100 \mu \mathrm{g} / \mathrm{ml}$ streptomycin (ATCC). Cells were maintained in T75 tissue culture flasks, and the medium was changed three times a week. Confluent cells were harvested by washing in phosphate-buffered saline (PBS) followed by trypsinisation (0.25\% in EDTA) for subculturing. All of the cell lines were purchased from ATCC, and culture reagents were purchased from Gibco-Life Technologies (Grand Island, NY, USA) unless otherwise stated.

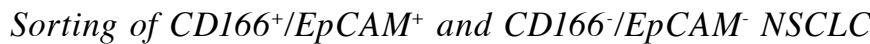
cell populations. The NSCLC cell lines (A549 and H2170) were harvested upon incubation with $0.25 \%$ trypsin (Life Technologies, Foster City, CA, USA) and washed with phosphate-buffered solution with 2\% FBS. The CD166-PE and EpCAM-FITC (BD Biosciences, San Jose, CA, USA) antibodies were used for CSC identification by flow cytometry. Briefly, cells were trypsinised, counted by a haemocytometer and transferred to $75-\mathrm{mm}$ polystyrene round-bottom test tubes (BD Falcon, NJ, USA) at a cell concentration of 
$1 \times 10^{6}$ cells $/ \mathrm{ml}$ and subsequently stained with $10 \mu \mathrm{l}$ of antibodies in the dark at $4^{\circ} \mathrm{C}$. The cells were then washed and filtered through a $40-\mu \mathrm{m}$ cell strainer to obtain a single-cell suspension before sorting. The expression of cancer stem cell markers (CD166 and EpCAM) was analysed and sorted using FACSAria III (BD, Biosciences). Gating used for the sorting of $\mathrm{CD}_{166} / \mathrm{EpCAM}^{+}(\mathrm{Q} 2)$ and CD166 /EpCAM ${ }^{-}$(Q3) NSCLC cell lines is depicted in Fig. 3.

Spheroid assay and self-renewal capacity. Sorted lung tumour cells $\left(1.0 \times 10^{3}\right.$ cells $\left./ \mathrm{ml}\right)$ were suspended in serum-free medium containing DMEM F12 (Gibco) supplemented with $10 \mathrm{ng} / \mathrm{ml}$ fibroblast growth factor (bFGF), $1 \%$ of B27, $20 \mathrm{ng} / \mathrm{ml}$ of EGF, $1 \%$ antibiotic-antimycotic, (all purchased from Life Technologies) and seeded in an 96-well ultra-low attachment (ULA) dish. Spheroid formation was assessed by light microscopy after 20 days of culture. Self-renewal capabilities were also evaluated by monitoring single cells using the live cell analyser (JuLI ${ }^{\mathrm{TM}} \mathrm{Br}$; NanoEnTek, CA, USA).

Preparation of curcumin and cisplatin stock. Curcumin (Sigma-Aldrich, St. Louis, MO, USA) was dissolved in $1 \mathrm{ml}$ DMSO to make a stock solution of $10 \mathrm{mM}$. The curcumin stock was then diluted in complete RPMI-1640 medium to provide a substock and final working concentrations. Cisplatin (Sigma-Aldrich) was prepared as a $10 \mathrm{mM}$ stock in $0.9 \%$ sodium chloride $(\mathrm{NaCl})$ and was diluted in complete RPMI-1640 medium to provide a substock. The solution was filtered through a $0.22-\mu \mathrm{m}$ membrane, aliquoted and stored at $-20^{\circ} \mathrm{C}$ until further use.

Inhibitory concentration $\left(I C_{50}\right)$ of single treatments (curcumin and/or cisplatin) in the NSCLC cell lines. $\mathrm{IC}_{50}$ values for the single treatment with either curcumin and cisplatin of NSCLC cell lines were assessed by the MTS [3-(4,5-dimethylthiazol-2-yl)-2H-tetrazolium, inner salt] assay purchased from Promega (Madison, WI, USA). Tumour cells were plated at a density of $1 \times 10^{4}$ cells/well in 96-well plates and incubated overnight in humidified air with $5 \% \mathrm{CO}_{2}$ at $37^{\circ} \mathrm{C}$. NSCLC cells were then treated with a working concentration of curcumin $(10,20,30$ and $40 \mu \mathrm{M})$ and cisplatin $(5,10,15,20$ and $25 \mu \mathrm{M})$ for $48 \mathrm{~h}$. After a 48-h incubation, $15 \mu \mathrm{l}$ of MTS solution was added to each well and incubated for another $4 \mathrm{~h}$. Solubilisation solution $(100 \mu \mathrm{l})$ was later added to the cells, and the absorbance at $570 \mathrm{~nm}$ was measured using Odyssey ${ }^{\circledR}$ SA Imaging System (Li-Cor, Lincoln, NE, USA), using wells without cells as the blank. Cell viability was calculated according to the following formula: Cell viability $(\%)=$ cells $($ sample)/cells (control) x 100 and $\mathrm{IC}_{50}$ was calculated using log formula.

$I C_{50}$ of curcumin sensitisation prior to cisplatin treatment in the NSCLC cell lines. In order to evaluate the efficacy of curcumin sensitisation prior to cisplatin treatment in NSCLC cell lines, both A549 and H2170 cells were initially sensitised/cultured with different doses of curcumin $(10,20,30$ and $40 \mu \mathrm{M})$ for $24 \mathrm{~h}$, followed by low dose cisplatin $(<3 \mu \mathrm{M})$ for another $24 \mathrm{~h}$. Briefly, the tumour cells were seeded $\left(1.0 \times 10^{5}\right.$ cells/well $)$ in 6 -well plates and sensitised with different doses of curcumin for $24 \mathrm{~h}$. On the following day, the cells were harvested and seeded again in 96 -well plates $\left(1.0 \times 10^{4}\right.$ cells/well) with medium containing cisplatin (low dose) for another $24 \mathrm{~h}$. At the end of the experiment, $15 \mu 1$ of MTS solution was added to each well and incubated for another $4 \mathrm{~h}$. Solubilisation solution $(100 \mu \mathrm{l})$ was later added to the cells, and the absorbance at $570 \mathrm{~nm}$ was measured using Odyssey SA Imaging System, using wells without cells as the blank.

Toxicity of curcumin and cisplatin in the human lung fibroblast (IMR-90) cell line. The $\mathrm{IC}_{50}$ values of both curcumin and cisplatin in the A549 and $\mathrm{H} 2170$ cells were tested on IMR-90 cells to evaluate the toxic effect of curcumin and cisplatin on normal cells. IMR-90 cells were seeded overnight in 96-well plates at a density of $1.0 \times 10^{4}$ cells/well in $100 \mu 1$ complete MEM- $\alpha$. Subsequently, $100 \mu 1$ of either curcumin and/or cisplatin (concentration based on $\mathrm{IC}_{50}$ of $\mathrm{A} 549$ and $\mathrm{H} 2170$ ) was added to the cells and incubated for $48 \mathrm{~h}$. The viability of the IMR-90 cells was assessed by adding $10 \mu \mathrm{l}$ of Presto Blue (BD Pharmingen, Franklin Lakes, NJ, USA) to each well and incubated for $2 \mathrm{~h}$ before the absorbance was measured at $570 \mathrm{~nm}$.

Apoptosis assay. The apoptosis assay was conducted using the Annexin V/propidium iodide (PI) apoptosis kit purchased from BD Pharmingen. In brief, $9.0 \times 10^{5}$ cells/well of sorted and unsorted NSCLC cells were seeded into 6-well plates and incubated overnight. Direct combination (synergistic effects) of both curcumin and cisplatin on the NSCLC cell lines was performed by incubation of the cells in medium containing the single treatment (cisplatin or curcumin) and combination of both using the $\mathrm{IC}_{50}$ doses for $48 \mathrm{~h}$. Indirect combination (sensitising effects) of curcumin was performed by incubating the NSCLC cell lines with curcumin ( $\mathrm{IC}_{50}$ value) for $24 \mathrm{~h}$, followed by incubation with low dose cisplatin $(3 \mu \mathrm{M})$ for another $24 \mathrm{~h}$. After treatments for $48 \mathrm{~h}$ (synergistic and sensitisation), both NSCLC cell lines were harvested by trysinisation and collected by centrifugation. The cell pellet was suspended in $100 \mu \mathrm{l}$ of $1 \mathrm{X}$ Annexin V binding buffer (Becton Dickinson BD) and $1 \mu \mathrm{l}$ of Annexin V-FITC was added. Antibody incubation was performed at $4^{\circ} \mathrm{C}$ for $20 \mathrm{~min}$, and $1 \mu \mathrm{l}$ of PI was later added before FACS acquisition. Stained cells were subjected to flow cytometric analysis using a FACSCalibur instrument (Becton Dickinson BD), and a total of 10,000 events were acquired and analyzed using Cell Quest software (Becton Dickinson BD).

Scratch-wound/migration assay. Briefly, sorted and unsorted NSCLC cells were seeded at a density of $\sim 3-4 \times 10^{5}$ cells/well in complete medium and grown overnight to a $90 \%$ confluent monolayer. The next day, the cells were treated with colcemide $(10 \mu \mathrm{g} / \mathrm{ml})$ for $2 \mathrm{~h}$ for cell synchronisation. After incubation, a scratch wound was inflicted using a sterile $200-\mu$ l pipette tip and gentle washing was carried out twice using PBS to remove debris. Cells were then incubated with $2 \mathrm{ml}$ of media containing both single treatments (cisplatin and curcumin) and/or the combination of both for another $48 \mathrm{~h}$. The concentration of curcumin and cisplatin (single treatments and/or combination) used for the assay was based on the $\mathrm{IC}_{50}$ values evaluated on both A549 and H2170 cells. Images of migrated cells (five fields of each triplicate well) were captured using relief contrast microscopy at x40 magnification (Olympus IX 71; Olympus, Tokyo, Japan) and analysed for $48 \mathrm{~h}$. The 
Table I. Human primer sequences used for qRT-PCR.

\begin{tabular}{|c|c|c|c|c|}
\hline Gene & Accession & Sense primer & Antisense primer & $\begin{array}{l}\text { Product } \\
\text { size (bp) }\end{array}$ \\
\hline Apaf 1 & NM_013229.2 & CACGTTCAAAGGTGGCTGAT & TGGTCAACTGCAAGGACCAT & 214 \\
\hline Cytochrome $c$ & NM_018947.5 & GGAGGCAAGCATAAGACTGG & GTCTGCCCTTTCTCCCTTCT & 267 \\
\hline Caspase-9 & XM_005246014.1 & TGTGGTGGTCATCCTCTCTCA & GTCACTGGGGGTAGGCAAACT & 331 \\
\hline p21 & NM_000389.4 & CTCAGAGGAGGCGCCATG & GGGCGGATTAGGGCTTCC & 517 \\
\hline Cyclin D1 & XM_006718653.1 & CGGAGGACAACAAACAGATC & GGGTGTGCAAGCCAGGTCCA & 350 \\
\hline GAPDH & NM_001289746.1 & TGAAGGTCGGAGTCAACGGATT & CATGTGGGCCATGAGGTCCACCAC & 530 \\
\hline
\end{tabular}

Table II. $\mathrm{IC}_{50}$ values were determined by proliferation assays as specified in Materials and methods.

\begin{tabular}{lcc}
\hline & \multicolumn{2}{c}{$\mathrm{IC}_{50}$ values $(\mu \mathrm{M})$ for the treatments } \\
\cline { 2 - 3 } NSCLC cell lines & Curcumin & Cisplatin \\
\hline A549 & $40 \pm 9.3$ & $30 \pm 5.0$ \\
H2170 & $30 \pm 8.8$ & $7 \pm 0.8$
\end{tabular}

Results are the mean \pm standard deviation $(\mathrm{SD})$.

numbers of cells that migrated into the wound area were evaluated using the formula: Percentage of migrated cells $=$ [initial scratch (0 h) - final scratch (48 h)]/initial (0 h) x 100.

Post-treatment effects on CSC marker expression (CD326 and CD166) in NSCLC cells analysed by FACS. NSCLC cells (A549 and H2170) were seeded in 6-well plates at a density of $9.0 \times 10^{5}$ cells/well and incubated overnight. After incubation, the cells were treated with $\mathrm{IC}_{50}$ values of curcumin and cisplatin, respectively for $48 \mathrm{~h}$. Cells were then harvested and washed with ice-cold PBS. Antibodies (CD326 and CD166) (10 $\mu \mathrm{l})$ were added to each tube and incubated for another $20 \mathrm{~min}$ in the dark at $4^{\circ} \mathrm{C}$. The cells were then suspended in ice-cold PBS supplemented with 2\% FBS, and a total of 10,000 events were acquired and analysed using Cell Quest software (Becton Dickinson BD).

Quantitative real time-polymerase chain reaction ( $R T-q P C R)$. Initially, total RNA was extracted and evaluated for purity as previously described. Transcriptor First Strand cDNA synthesis kit (Roche Applied Science, Nonnenwald, Penzberg, Germany) was used to synthesise cDNA according to the protocols recommended by the manufacturer. Quantitative RT-PCR (qRT-PCR) was performed using the Light Cycler 480 (Roche, Mannheim, Germany), on sorted lung tumour cells subsequent to treatment either by single agent (cisplatin or curcumin) or direct combination of both (synergistic effects) based on the $\mathrm{IC}_{50}$ values. The qRT-PCR reaction was prepared using SYBR 1 Master Mix (Roche Applied Science, Penzberg, Germany) and primers as stated in Table I. PCR conditions were set under the following cycle conditions: pre-denaturation for 4 min at $95^{\circ} \mathrm{C}$ followed by 40 cycles consisting of denaturation at $95^{\circ} \mathrm{C}$ for $15 \mathrm{sec}$, annealing at $60^{\circ} \mathrm{C}$ for $30 \mathrm{sec}$ and extension at $72^{\circ} \mathrm{C}$ for $30 \mathrm{sec}$ followed by dissociation curve. The basic relative gene expression (RQ) was calculated using the $\Delta \Delta \mathrm{Ct}$ formula and the efficiency (E) of primer binding equal to 2 .

Statistical analysis. All data are expressed as the mean \pm standard deviation (SD) of three independent experiments. Comparison between two groups was performed using the two-tailed t-test. P-values of $<0.01$ were considered to indicate statistically significant differences.

\section{Results}

The $I C_{50}$ values of curcumin and cisplatin for both A549 and $H 2170$ cell lines. The $\mathrm{IC}_{50}$ values of $\mathrm{A} 549$ and $\mathrm{H} 2170$ cells treated with curcumin and cisplatin were assessed by MTS assay at $48 \mathrm{~h}$. The results showed that exposure of NSCLC cell lines (A549 and $\mathrm{H} 2170)$ to a range of curcumin $(\leq 40 \mu \mathrm{M})$ and cisplatin $(\leq 25 \mu \mathrm{M})$ concentrations resulted in $\mathrm{IC}_{50}$ values of 41 and $30 \mu \mathrm{M}$ and 33 and $7 \mu \mathrm{M}$, respectively (Fig. 1A and B). Furthermore, we noted that the $\mathrm{IC}_{50}$ values for both $\mathrm{A} 549$ and H2170 cells to curcumin were almost equal. However, the $\mathrm{IC}_{50}$ value of cisplatin in the $\mathrm{H} 2170$ cells was markedly lower compared to that for the A549 cells indicating higher sensitivity of $\mathrm{H} 2170$ cells to cisplatin-induced inhibition. Based on the $\mathrm{IC}_{50}$ value indicated, the combination of $41 \mu \mathrm{M}$ curcumin and $30 \mu \mathrm{M}$ cisplatin was selected for A549 cells and $33 \mu \mathrm{M}$ of curcumin and $7 \mu \mathrm{M}$ of cisplatin were selected for $\mathrm{H} 2170$ cells for further downstream study (Table II).

Curcumin sensitisation enhances the tumour growth inhibitory effect of low dose cisplatin. To determine whether curcumin sensitises NSCLC cell lines to the tumour inhibitory effect of low dose cisplatin $(\leq 3 \mu \mathrm{M})$, NSCLC cells (A549 and H2170) were incubated overnight with different doses of curcumin $(10,20,30$ and $40 \mu \mathrm{M})$, harvested and seeded again with low dose cisplatin $(\leq 3 \mu \mathrm{M})$ for another $24 \mathrm{~h}$. Treated NSCLC cells were subsequently evaluated for cell viability using the MTS assay. Treatment of the A549 and H2170 cells with curcumin (10-40 $\mu \mathrm{M})$ markedly enhanced the sensitivity of both NSCLC cell lines to cisplatin (Fig. 2A and B).

Treatment of both A549 and $\mathrm{H} 2170$ cells with $3 \mu \mathrm{M}$ cisplatin alone (low dose) was found to be ineffective to induce inhibition of growth in the NSCLC cell lines (tumour viability 80\%). However, this treatment became highly effective similar to the $\mathrm{IC}_{50}$ concentration (tumour viability $\sim 50 \%$ ) when both A549 and $\mathrm{H} 2170$ were initially sensitised to different concentrations 
A

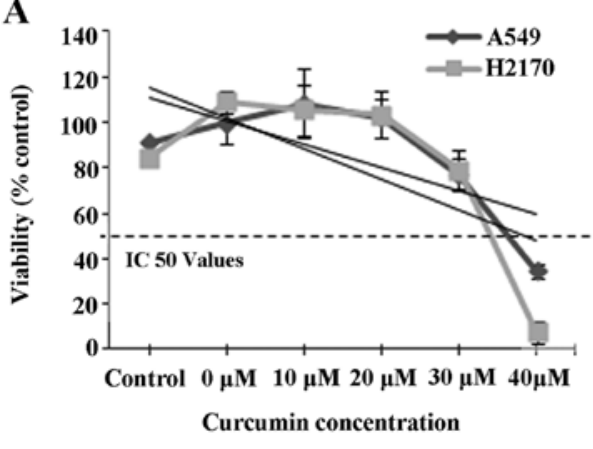

B

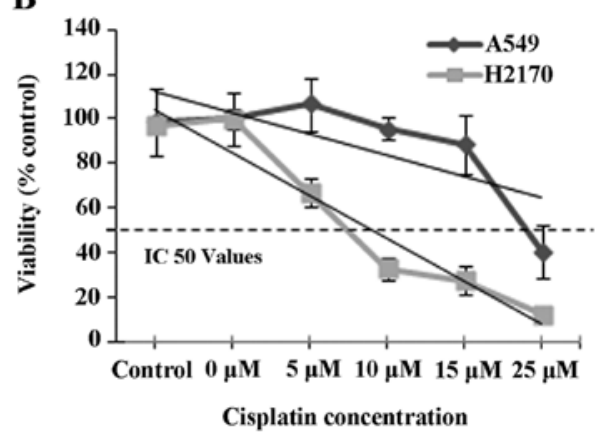

Figure $1 . \mathrm{IC}_{50}$ values of curcumin and cisplatin in NSCLC cell lines by MTT assay. The viability of A549 and H2170 cells was measured after a 48 -h treatment with the indicated concentrations of curcumin (A) and cisplatin (B).

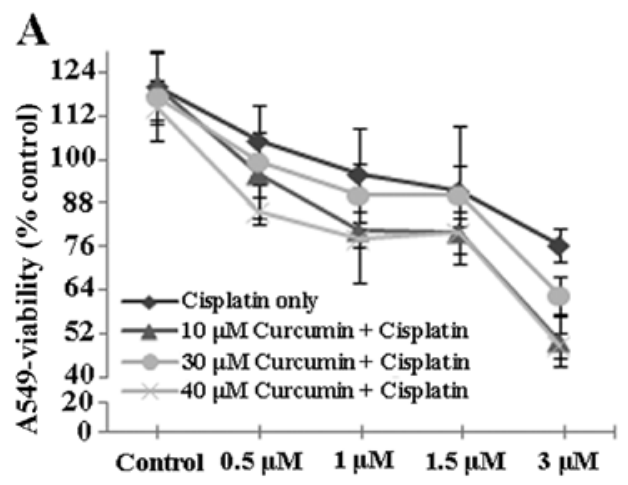

Cisplatin concentration
B

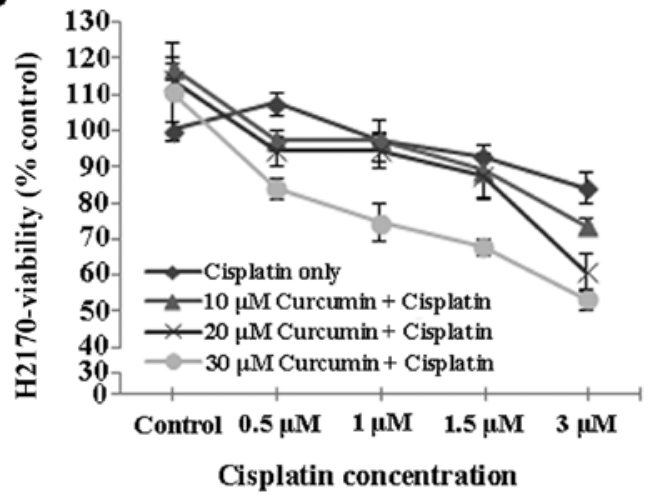

D

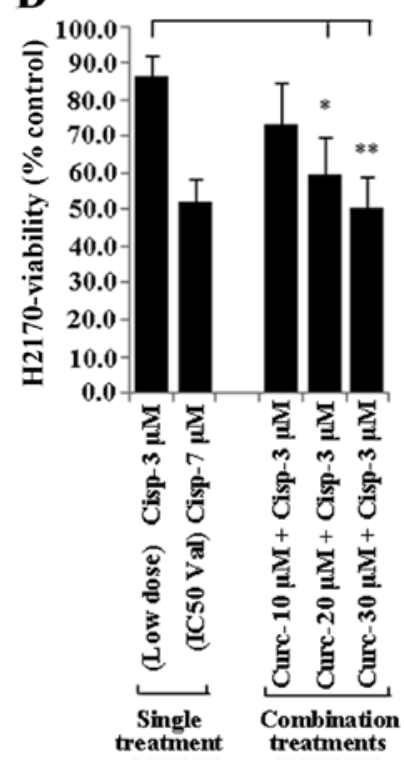

$\mathbf{E}$

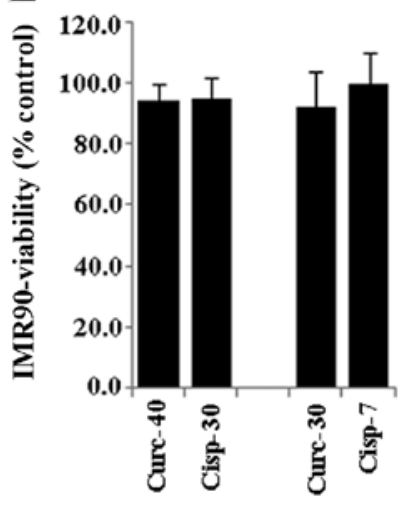

Treatments $\mu \mathrm{M}$

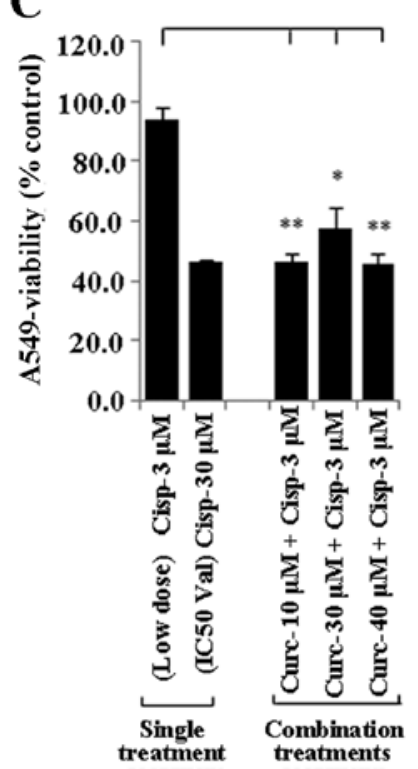

Figure 2. Curcumin sensitisation increases the efficacy of low dose cisplatin. Exposure of NSCLC cell lines (A549 and H2170) with different concentrations of curcumin (10-40 $\mu \mathrm{M})$ for $24 \mathrm{~h}$ prior to treatment with an ineffective low dose of cisplatin $(\leq 3 \mu \mathrm{M})$ increased the efficacy of cisplatin on A549 (A) and $\mathrm{H} 2170$ (B) cells as the percentage of viability was reduced compared to the basal (cisplatin only) level. Bar diagram showing that cell viability of the NSCLC cell lines was significantly inhibited to an average of $\sim 51.2$ and $\sim 54.9 \%$ (almost equal to the $\mathrm{IC}_{50}$ value) following the combination treatments as compared to the single treatment (cisplatin, $3 \mu \mathrm{M}$ ) in the A549 (C) and H2170 (D) cells, respectively. Moreover, exposure of IMR-90 cells to curcumin and cisplatin caused no growth inhibition (E); ${ }^{*} \mathrm{P}<0.01,{ }^{* *} \mathrm{P}<0.001$; t-test.

of curcumin (10-40 $\mu \mathrm{M})$ (Fig. 2C and D). Moreover, exposure of IMR-90 cells to the $\mathrm{IC}_{50}$ values of curcumin and cisplatin in both NSCLC cell lines did not induce toxicity to the cells, as the percentage of viability was higher than $90 \%$ (Fig. 2E). 
Table III. The percentage of subpopulations in NSCLC cells by CSC marker expression post-treatment.

Treatments

\begin{tabular}{lcccc} 
Cell lines & Subpopulations & Curcumin (\%) & Cisplatin (\%) & Combination (\%) \\
\hline A549 & CD166 $^{+} / \mathrm{EpCAM}^{+}$ & $25.2 \pm 3.2$ & $25.1 \pm 7.4$ & $34.6 \pm 0.7$ \\
& $\mathrm{CD}^{-} 166 / \mathrm{EpCAM}^{-}$ & $14.9 \pm 3.6$ & $21.4 \pm 4.2$ & $23.6 \pm 12.6$ \\
$\mathrm{H} 2170$ & $\mathrm{CD}^{+} 66^{+} / \mathrm{EpCAM}^{+}$ & $47.4 \pm 18.4$ & $50.1 \pm 14.3$ & $55.0 \pm 0.4$ \\
& $\mathrm{CD} 166 / \mathrm{EpCAM}^{-}$ & $1.3 \pm 0.2$ & $2.2 \pm 0.2$ & $1.7 \pm 0.4$
\end{tabular}

Subpopulation of $\mathrm{CD} 166^{+} / \mathrm{EpCAM}^{+}$cells showed higher marker expression at the basal level both in A549 and $\mathrm{H} 2170$ cells and were enriched upon the treatments. CD166/EpCAM cells were selected as a control for CD166 ${ }^{+} / \mathrm{EpCAM}^{+}$. Results are the mean \pm standard deviation $(\mathrm{SD})$.

A

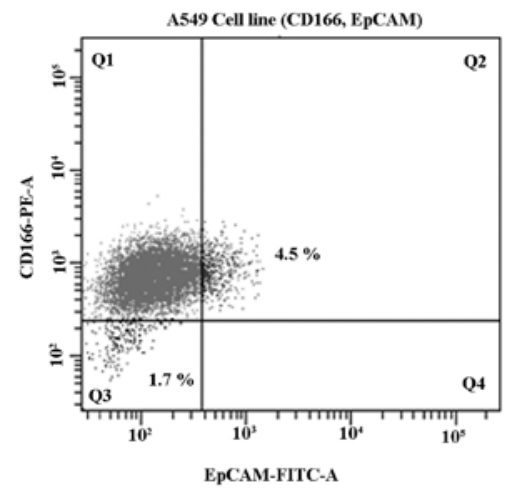

B

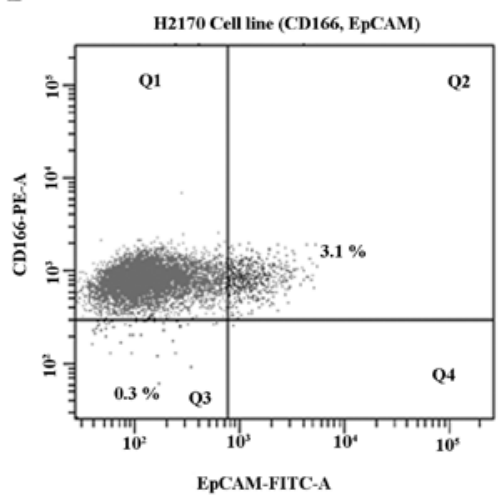

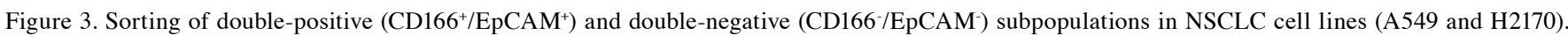
Both NSCLC cell lines were analysed for subpopulations using CD166-PE and EpCAM-FITC and sorted by flow cytometry. A549 cells showed 4.5\% (Q2) expression of double-positive and 1.7\% (Q3) expression of double-negative subpopulations (A), while H2170 presented with 3.1\% (Q2) double-positive and $0.3 \%(\mathrm{Q} 3)$ double-negative subpopulations (B).

Isolation of $\mathrm{CD} 166^{+} / \mathrm{EpCAM}^{+}$and $\mathrm{CD} 166^{-} / \mathrm{EpCAM}^{-}$subpopulations from the NSCLC cell lines. The expression of CSC markers (CD166 and EpCAM) in the NSCLC cell lines was studied and we found a small population of NSCLC cells (A549 and H2170) that showed positivity for CD166 and EpCAM (CD166 ${ }^{+} /$EpCAM $^{+}$) (Fig. 3). The NSCLC cells showed consistent double-positive expression of $\mathrm{CD}_{166^{+}} / \mathrm{EpCAM}^{+}$ ranging from 3.0 to $4.5 \%$ (Fig. 3). This was consistent with the characteristics of CSCs in a tumour population indicating that the expression of CSC markers should be within $\sim 4 \%$ of the total population (56). Moreover, the double-negative $\left(\mathrm{CD}_{166} / \mathrm{EpCAM}^{-}\right)$population was much lower in the NSCLC cell lines with 1.7 and $0.3 \%$ in both the A549 and $\mathrm{H} 2170$ cells, respectively (Fig. 3A and B). The CD166 ${ }^{+} / \mathrm{EpCAM}^{+}$and $\mathrm{CD} 166^{-} / \mathrm{EpCAM}^{-}$populations were sorted from the A549 and $\mathrm{H} 2170$ cells into a $15-\mathrm{ml}$ tube containing complete medium and transferred to a T75 flask for expansion and further downstream study.

Tumour sphere formation and self-renewal capacity of the $C D 166^{+} / E_{p C A M}$ subpopulation. The ability of the double-positive $\left(\mathrm{CD} 166^{+} / \mathrm{EpCAM}^{+}\right)$subpopulation sorted from the NSCLC cell lines to form three-dimensional spheres in serum-free medium containing stem cell growth factors (EGF and $\mathrm{bFGF}$ ) on non-adherent plates was examined. The sorted NSCLC cells grew as anchorage-independent spheres after
14 days of culture (Fig. 4B). We observed that the isolated $\mathrm{CD} 166^{+} / \mathrm{EpCAM}^{+}$subpopulations of both A549 and $\mathrm{H} 2170$ cells were able to form tumour spheres with an average size ranging from 50 to $200 \mu \mathrm{m}$ in diameter (Fig. 4B). We also noted that the $\mathrm{CD}_{166} / \mathrm{EpCAM}^{+}$subpopulation isolated from A549 cells had the ability for self-renewal and produced daughter cells, which is an important characteristic of CSCs (Fig. 5B). However, there were cells observed as non-dividing (Fig. 5A), which were a dormant phenotype of CSCs.

Combination of curcumin and cisplatin enriches the $\mathrm{CD} 166^{+} / \mathrm{EpCAM}^{+}$CSC subpopulation. In order to study the combination effects of curcumin and cisplatin on the regulation of CSC subpopulations, the expression of two combination markers (CD166 and EpCAM) which were previously described as markers of lung cancer CSCs, were evaluated in the NSCLC cell lines (A549 and H2170) after treatment with either a single agent of curcumin or cisplatin, or a combination of both. Treatment of A549 and H2170 cells with the combination of curcumin and cisplatin led to an average increase of $\sim 10$ and $\sim 6 \%$ expression of the double-positive $\left(\mathrm{CD}_{166^{+}} / \mathrm{EpCAM}^{+}\right) \mathrm{CSC}$ subpopulation, respectively, as compared to both curcumin and cisplatin treatment alone (Table III). Combination treatment only led to $\sim 2 \%$ increase and a slight reduction $(\sim 0.5 \%)$ in the $\mathrm{CD}^{166} / \mathrm{EpCAM}^{-}$subpopulation noted in the A549 and $\mathrm{H} 2170$ 
A

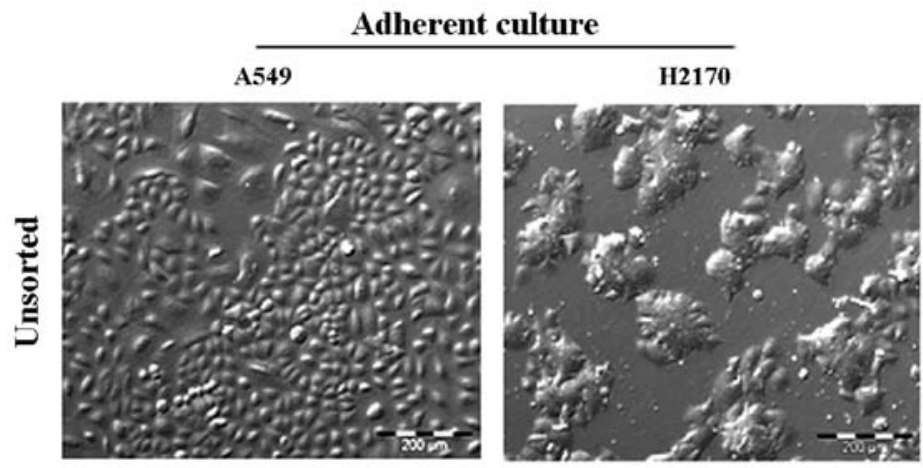

B

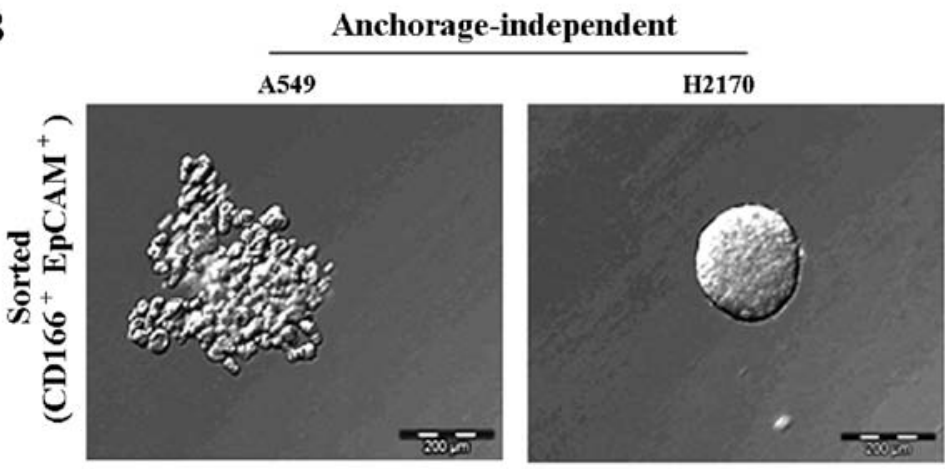

Figure 4. Isolated CSCs from NSCLC cell lines formed anchorage-independent self-renewing tumour spheres. Each of the cell lines exhibits a unique morphology observed as monolayers in the A549 cells, while $\mathrm{H} 2170$ as colonies in adherent culture (A). Anchorage-independent spheres formed by CD166 ${ }^{+} /$ $\mathrm{EpCAM}^{+}$cells isolated from both A549 and $\mathrm{H} 2170$ cells, 14 days of culture in serum-free stem cell medium (B).

A

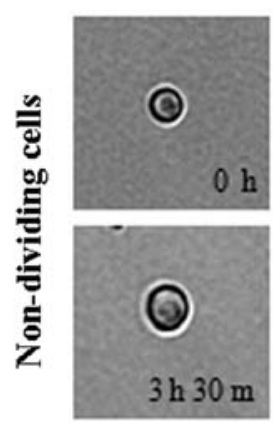

B
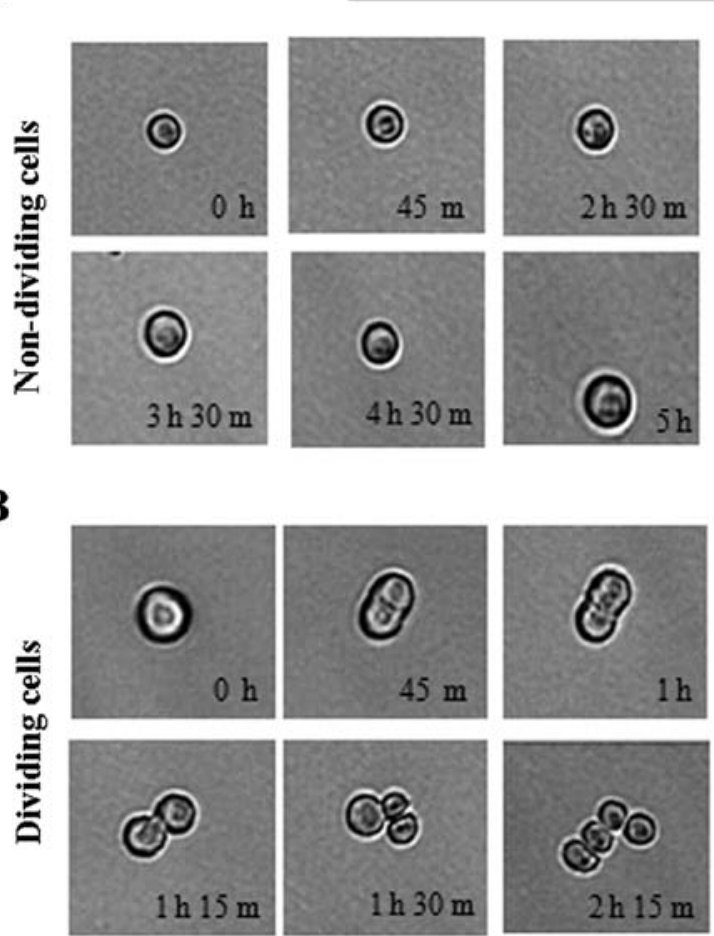

\section{$\mathrm{A549}\left(\mathrm{CD}^{166} 6^{+} / \mathrm{CD}^{2} 6^{+}\right)$}

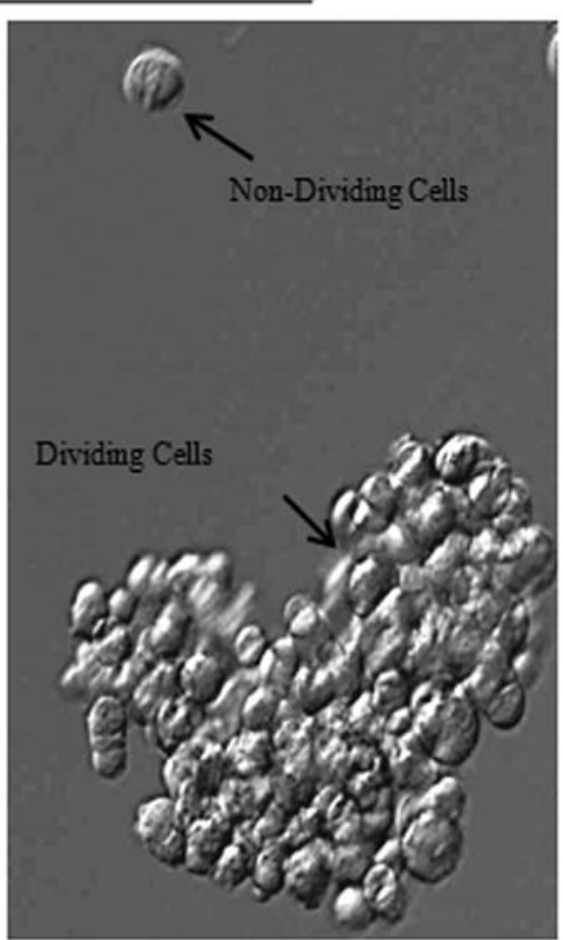

Figure 5. Phase-contrast images of a single $\mathrm{CD} 166^{+} / \mathrm{EpCAM}^{+}$cell derived from A549 cells cultured in 96 -well plates under anchorage-independent, serum-free conditions. Sorted $\mathrm{CD}_{166} / \mathrm{EpCAM}^{+}$cells either in the non-dividing phase (A) or actively dividing phase (B) were recorded at different time points as indicated.

cells, correspondingly (Table III), suggesting that the combination of both curcumin and cisplatin synergistically acted to enrich the double-positive $\left(\mathrm{CD} 166^{+} / \mathrm{EpCAM}^{+}\right)$subpopulation as compared to each single treatment alone. 
A

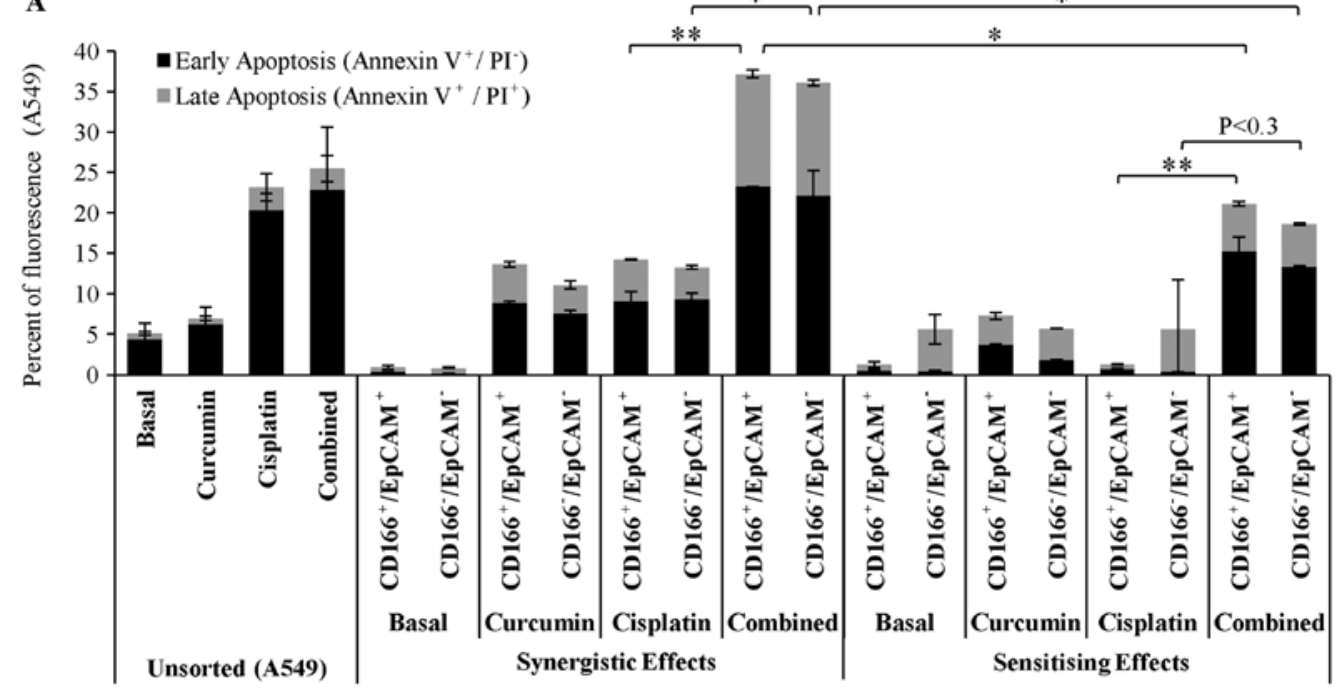

B
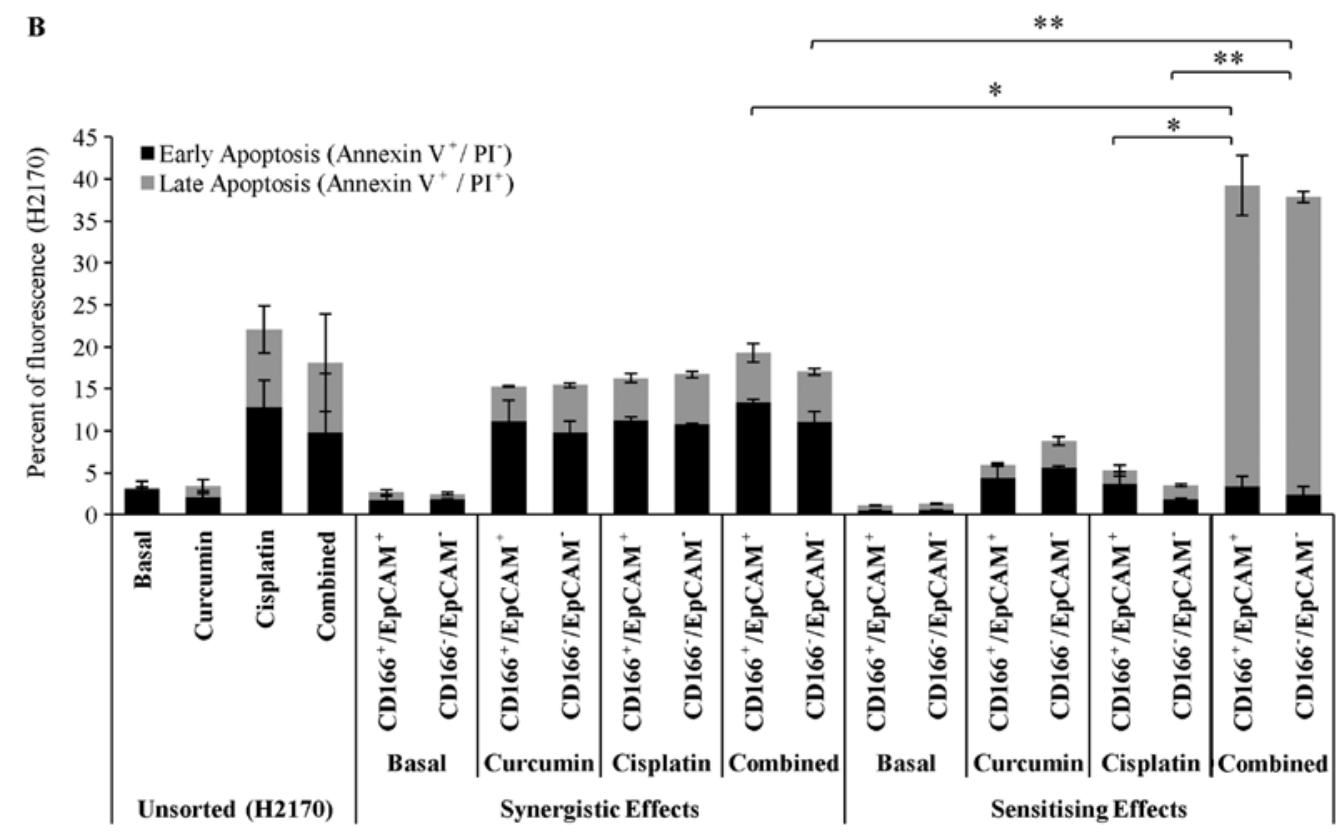

Figure 6. Curcumin improves the sensitivity of the CSC subpopulation $\left(\mathrm{CD}_{166} / \mathrm{EpCAM}^{+}\right)$to cisplatin-induced apoptosis. Both sorted and unsorted NSCLC cells lines were incubated with curcumin either by direct combination (synergistic) with cisplatin or indirect combination (sensitising) for $48 \mathrm{~h}$, and the percentage of apoptosis was detected by flow cytometry using Annexin V/propidium iodide (PI) staining. The combined treatment significantly increased the percentage of apoptosis in the double-positive $\left(\mathrm{CD}^{2} 66^{+} / \mathrm{EpCAM}^{+}\right) \mathrm{CSC}$ subpopulation by $22 \%$ (synergistic) and 18\% (sensitising) as compared to cisplatin alone (A). An increase in the percentage of apoptosis by $36 \%$ for the sensitising effect was noted in the double-positive $\left(\mathrm{CD}^{2} 66^{+} / \mathrm{EpCAM}^{+}\right)$subpopulation of H2170 cells compared to cisplatin alone. No apparent changes were observed between treatments for the synergistic effect, suggesting that single treatments of curcumin and cisplatin alone induced a maximum response to the cells (B). ${ }^{*} \mathrm{P}<0.01,{ }^{* * *} \mathrm{P}<0.001$; t-test.

Curcumin enhances the sensitivity of the CSC subpopulation

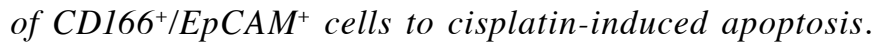
The apoptotic effects of the combined treatment of curcumin either by synergism with cisplatin or sensitising effects prior to treatment with low dose cisplatin in the double-positive $\left(\mathrm{CD} 166^{+} / \mathrm{EpCAM}^{+}\right) \mathrm{CSC}$ subpopulation was examined using the apoptosis assay (Annexin V/PI) $48 \mathrm{~h}$ post-treatment. The unsorted A549 and $\mathrm{H} 2170$ cells were used as a control to indicate the basal level of apoptosis following the treatments (Fig. 6). As shown for the synergistic effect of curcumin (Fig. 6A); the results indicated that single treatments of curcumin and cisplatin induced apoptosis in the double-positive $\left(\mathrm{CD}^{2} 66^{+} / \mathrm{EpCAM}^{+}\right)$ CSC subpopulation of A549 cells to an average of 14 and 15\% following $48 \mathrm{~h}$ of treatments. Moreover, the apoptotic effect was significantly increased to an average of $\sim 37 \%$ in the double-positive $\left(\mathrm{CD} 166^{+} / \mathrm{EpCAM}^{+}\right) \mathrm{CSC}$ subpopulation as these two treatments were applied simultaneously. The results also showed that curcumin sensitisation prior to treatment with low dose cisplatin in the double-positive $\left(\mathrm{CD}_{166} / \mathrm{EpCAM}^{+}\right)$ CSC subpopulation of A549 cells substantially increased the percentage of apoptosis by $\sim 20 \%$ as compared to treatment with low dose cisplatin with only $2 \%$ apoptosis (Fig. 6A).

There were no significant changes in the percentage of apoptosis between the single treatment of curcumin or cisplatin, and the combination treatments by synergistic effects on sorted H2170 cells (Fig. 6B). This result suggests that the cells are highly sensitive to both curcumin and cisplatin; the $\mathrm{IC}_{50}$ concentrations of both treatments given to the cells have 
A

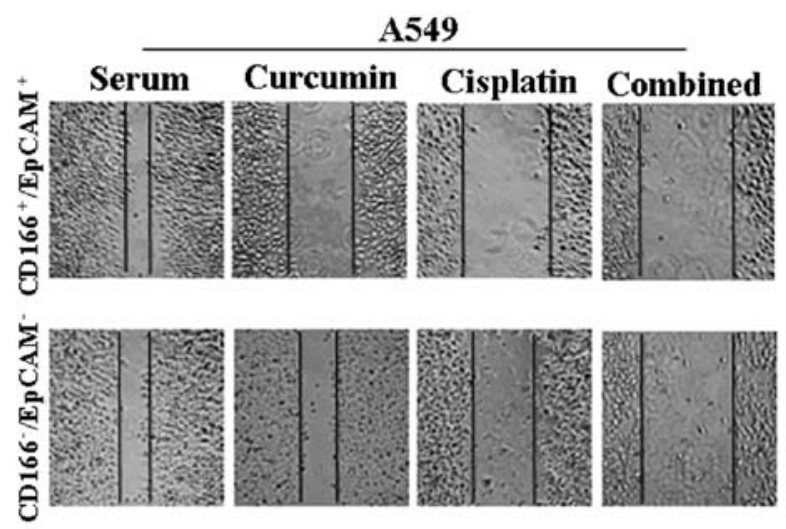

C

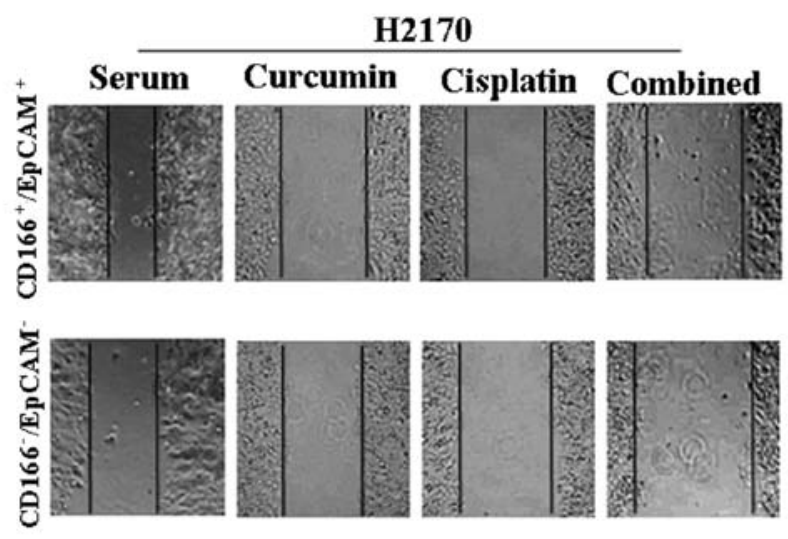

B

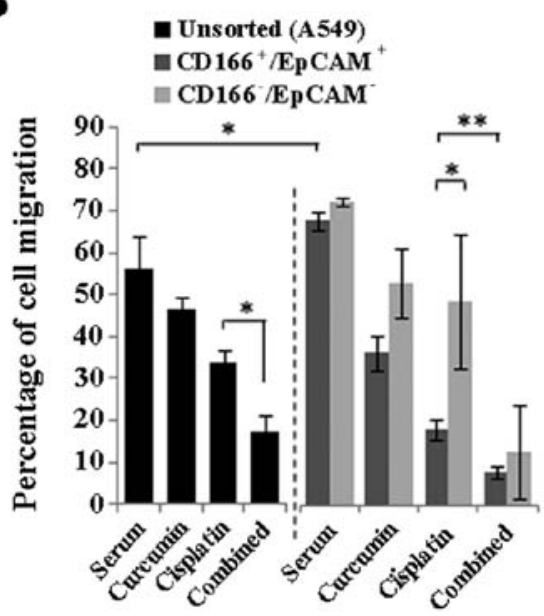

D

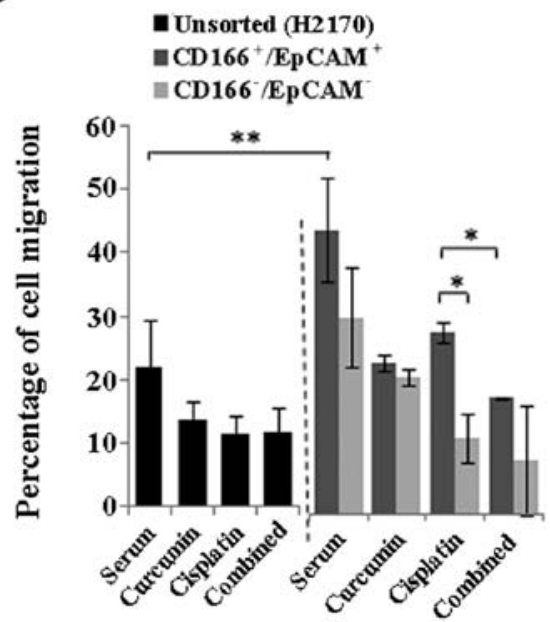

Figure 7. Curcumin enhances the cisplatin-induced metastatic inhibition of the CSC subpopulation $\left(\mathrm{CD}^{2} 66^{+} / \mathrm{EpCAM}^{+}\right)$in the $\mathrm{NSCLC}$ cell lines. Representative photomicrographs and analysis of wound closure are presented for sorted NSCLC cell lines after $48 \mathrm{~h}$ of curcumin treatment either alone or in combination with cisplatin using the $\mathrm{IC}_{50}$ values $\left(\mathrm{A}\right.$ and $\mathrm{C}$ ). Higher migratory potential was noted in the double-positive $\left(\mathrm{CD} 166^{+} / \mathrm{EpCAM}^{+}\right) \mathrm{CSC} \mathrm{subpopulation}$ as compared to the unsorted of both NSCLC cell lines (B and D). Combination of both curcumin and cisplatin markedly inhibited the migration of CSCs in both the A549 and H2170 cells, suggesting better efficacies of the combination treatment for inhibiting the highly migratory CSC subpopulation (B and D). * $<0.01$, ${ }^{* *} \mathrm{P}<0.001$; t-test.

already induced a maximal response. Interestingly, we noted that by sensitising the double-positive $\left(\mathrm{CD} 166^{+} / \mathrm{EpCAM}^{+}\right) \mathrm{CSC}$ subpopulation of $\mathrm{H} 2170$ cells to curcumin, prior to treatment with low dose cisplatin notably enhanced its apoptotic effect by $40 \%$, compared to only $20 \%$ apoptosis as observed for the synergistic treatments. Combination treatments by sensitisation of the double-positive $\mathrm{CD} 166^{+} / \mathrm{EpCAM}^{+} \mathrm{CSC}$ subpopulation of $\mathrm{H} 2170$ cells to curcumin, also significantly increased the percentage of late apoptosis to $35 \%$, compared to treatment with low dose cisplatin with only $4 \%$ detected (Fig. 6B).

Curcumin enhances the cisplatin-induced inhibition of the metastasis of the highly migratory CSC subpopulation $\left(C D 166^{+} / E p C A M^{+}\right)$in the NSCLC cell lines. To evaluate the migratory potential of the CSC subpopulation in the NSCLC cell lines (A549 and H2170) and the effects of curcumin either alone or in combination with cisplatin to inhibit the migration of these cells; scratch wound (migration) assay was performed in the sorted $\left(\mathrm{CD}_{166} / \mathrm{EpCAM}^{+}\right.$and $\left.\mathrm{CD} 166^{-} / \mathrm{EpCAM}^{-}\right)$and unsorted NSCLC cell lines $48 \mathrm{~h}$ post-treatment. As depicted in Fig. 7B and D, the double-positive $\left(\mathrm{CD} 166^{+} / \mathrm{EpCAM}^{+}\right) \mathrm{CSC}$ subpopulation had a significantly higher migratory potential as compared to the unsorted cells observed for both NSCLC cell lines. The combination of curcumin and cisplatin reduced the percentage of cell migration from 33.8 (cisplatin) to $17.3 \%$ (combined) in the unsorted A549 cells (Fig. 7B) with no apparent changes as noted in the H2170 cells (Fig. 7D). Furthermore, combined treatment markedly inhibited the migration of the $\mathrm{CD} 166^{+} / \mathrm{EpCAM}^{+}$subpopulation from 19.6 to $8.7 \%$ in the A549 cells and from 32.6 to $20.9 \%$ in the $\mathrm{H} 2170$ cells as compared to cisplatin treatment alone (Fig. 7B and D). Moreover, curcumin alone was able to inhibit the migration of the $\mathrm{CD} 166^{+} / \mathrm{EpCAM}^{+}$subpopulation in both the A549 and $\mathrm{H} 2170$ cells signifying the potential of curcumin on CSC inhibition. A higher cell migration was also noted in the $\mathrm{CD} 166^{-} / \mathrm{EpCAM}^{-}$compared to the $\mathrm{CD} 166^{+} / \mathrm{EpCAM}^{+}$subpopulation for the cisplatin treatment alone in A549 cells, while an opposite effect was noted in the $\mathrm{H} 2170$ cells (Fig. 7B and D). However, there were no differences in the percentage of cell

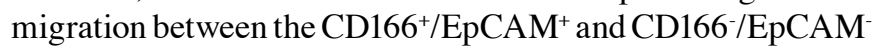



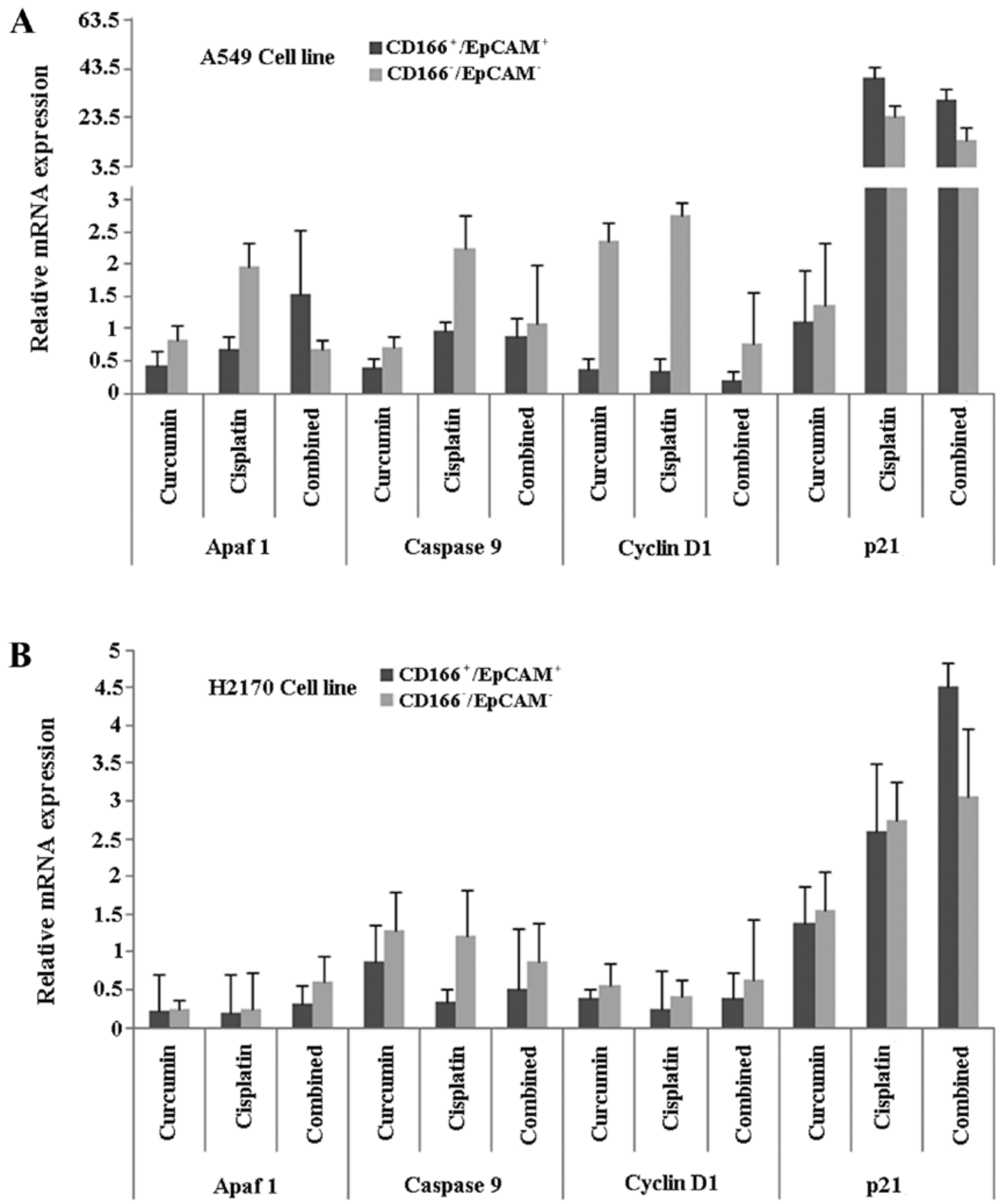

Figure 8. The mRNA expression of apoptotic (Apaf1 and caspase-9) and cell cycle-regulating (cyclin D1 and p21) genes, $48 \mathrm{~h}$ post-treatment. The mRNA expression of selected genes was evaluated in A549 (A) and H2170 (B) cells after treatment with the combination of curcumin and cisplatin by direct combination of both (synergistic effects) based on the $\mathrm{IC}_{50}$ values.

subpopulation for the combination treatment in both NSCLC cell lines (Fig. 7B and D).

Curcumin together with cisplatin increases the positive expression of apoptotic and cell cycle-regulating genes in the sorted cells. Finally, in order to understand the mechanisms behind the process, we investigated specific genes involved in apoptosis (Apaf1, cytochrome $c$ and caspase-9) and cell cycle regulation (cyclin D1 and p21) in the double-positive $\left(\mathrm{CD}_{166} / \mathrm{EpCAM}^{+}\right) \mathrm{CSC}$ subpopulation of both A549 and $\mathrm{H} 2170$ cells, after induction of treatments using either curcumin or cisplatin, and the combination of both. The results showed that the relative gene expression level of Apaf1 was higher in the combined treatment group compared to the single treatments (curcumin or cisplatin) in the $\mathrm{CD} 166^{+} / \mathrm{EpCAM}^{+}$subpopulation of A549 cells (Fig. 8A). Furthermore, the expression of p21 was high, with low expression of the cyclin D1 gene, in the $\mathrm{CD}_{166} / \mathrm{EpCAM}^{+}$subpopulation of both the A549 and

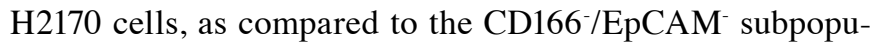
lation in the combined treatment group (Fig. 8A and B). Combined treatments induced high expression of caspase- 9 in the $\mathrm{CD}_{166} / \mathrm{EpCAM}^{+}$subpopulation of A549, compared to single treatments of curcumin (Fig. 8A). On the other hand, the expression of caspase- 9 was consistently low in the 
$\mathrm{CD} 166^{+} / \mathrm{EpCAM}^{+}$subpopulation of $\mathrm{H} 2170$ cells for all of the treatments (Fig. 8B).

\section{Discussion}

The existence of chemoresistant tumour cells is one of the major obstacles reducing the efficacies of antitumour agents for cancer treatments. Studies have demonstrated that CSCs, as the main component in the tumour that drives tumour invasion, metastasis and relapse, are also believed to be the main reason for the chemoresistant phenotype. Currently, cisplatin and other platinum-based compounds are the most effective agents for the treatment of lung cancer patients, and they are usually combined with other agents such as docetaxel, gemcitabine and paclitaxel to yield higher efficacies (57). However the use of conventional drugs is limited due to the side effects and the resistant phenotype acquired by tumours $(58,59)$. Active compounds derived from plants, microbes and marine organisms have been the interest of many investigators recently. These active compounds either in their crude or purified extracts have been shown to either have synergistic effects with chemotherapy or sensitising effects on CSCs, thus yielding superior efficacy as compared to chemotherapy alone $(60,61)$. It is also suggested that the sensitising effects of these active compounds, might be useful to reduce the toxicity in patients by high dose chemotherapy.

In the present study, we studied the efficacy of curcumin, a natural compound extracted from Curcuma longa, either alone or in combination with cisplatin on the inhibition of double-positive $\left(\mathrm{CD}_{166} / \mathrm{EpCAM}^{+}\right) \mathrm{CSC}$ subpopulation sorted from NSCLC cell lines (A549 and H2170), that we previously characterised (55). Curcumin cytotoxicity in NSCLC cell lines indicated by the $\mathrm{IC}_{50}$ values (Table II) showed that the agent, similar to cisplatin, is able to inhibit NSCLC cell proliferation. Moreover, sensitisation of both NSCLC cell lines using curcumin prior to treatment with low dose cisplatin, significantly reduced the percentage of viability in both the NSCLC cell lines compared to the treatment with low dose cisplatin (Fig. 2C and D). These results are in agreement with studies that have shown similar findings on the ability of curcumin to enhance the effects of cisplatin in NSCLC cell lines $(23,62)$. These findings might also suggest that through the sensitising effects of curcumin, a combination of both curcumin and cisplatin could potentially be used as a treatment strategy to compliment the effects of low dose ciplatin. Thus, a higher therapeutic efficacy with lower toxicity can be achieved. Moreover, the $\mathrm{IC}_{50}$ value of curcumin, as well as cisplatin, that were evaluated in the NSCLC cell lines did not induce cytotoxicity on normal epithelial cells (IMR-90) (Fig. 2E) indicating that the target effects of both agents are tumour-specific.

The presence of CSCs as part of the tumour population has recently become the interest of many investigators. Most studies believe that by specifically targeting these subpopulations, the efficacy of treatments could be enhanced and eventually might reduce the chances for relapse (56). However, the major obstacles to this approach are the resistance characteristics of CSCs upon treatment (63). We noted that curcumin enhanced the induction of apoptosis by cisplatin in the $\mathrm{CD} 166^{+} / \mathrm{EpCAM}^{+}$ subpopulation in both A549 and H2170 cells by either sensi- tising or synergistic effects (Fig. 6). Interestingly, in H2170 cells, synergistic effect of curcumin by direct combination with cisplatin did not induce significant changes in the percentage of apoptosis in the $\mathrm{CD} 166^{+} / \mathrm{EpCAM}^{+}$subpopulation of this cell line, as compared to cisplatin alone (Fig. 6B). However, the percentage of apoptosis was significantly increased when the subpopulation was initially sensitised to curcumin, prior to treatment with low dose cisplatin (Fig. 6B). Based on this observation, we believe that curcumin has the potential to alter the phenotype of NSCLC cells to treatments by enhancing the sensitivity of CSCs to chemotherapy. This theory is supported by few studies that have shown the same effects in several tumour models such as breast tumours and colon cancer, where these investigators have attributed the effects of curcumin on the inhibition of CSCs $(64,65)$. These results also suggest that the approach of utilising curcumin either by direct combination (synergistic) or indirect combination (sensitising) with cisplatin should be taken into consideration if efficacy of the combined treatment is to be optimal on inhibiting the CSC subpopulation. Moreover, analysis on the gene expression level in the $\mathrm{CD}_{166} / \mathrm{EpCAM}^{+}$subpopulation of both A549 and H2170 cells from our previous study also demonstrated that there are variations in the tumourigenic mRNA expression between this subpopulation that we believed could further be attributed to the heterogeneity of CSCs to treatment outcomes (55).

The properties of CSCs, a subpopulation of cells that exhibit stem cell characteristics and contribute to treatment resistance, have been suggested as a candidate for mediating metastatic progression (66). In contrary, other cancer cells which do not exhibit stem cell characteristics and metastasise into distant tissue and confront an entirely new microenvironment may often be unable to colonise and grow. Only CSCs with high EMT (epithelial to mesenchymal transition) characteristics and a resistant phenotype have the capacity to metastasise and survive long enough and arrive at distant sites (67). Our results presented here showed that the $\mathrm{CD}_{166} / \mathrm{EpCAM}^{+}$ subpopulation of both NSCLC cell lines have substantially higher migratory potential as compared to the unsorted cells (Fig. 7), consistent with the high metastatic characteristics of CSCs, that have been shown by several studies $(68,69)$. Furthermore, a combination of both curcumin and cisplatin markedly inhibited the migration of the $\mathrm{CD}_{166} / \mathrm{EpCAM}^{+}$ subpopulation in both A549 (Fig. 7A and B) and H2170 cells (Fig. 7C and D) compared to cisplatin treatment alone, indicating that the combination treatment induced superior effects on inhibiting the migration of CSCs. This finding might also indicate that the synergistic effects of both treatments could be utilised as a treatment strategy to combat the highly migratory CSC subpopulation. Thus, the probability of metastatic progression after chemotherapy in NSCLC may be reduced.

We observed that the combination treatment reduced the mRNA expression of cyclin D1 and induced p21 expression in the $\mathrm{CD}_{166} / \mathrm{EpCAM}^{+}$subpopulation in both the A549 and $\mathrm{H} 2170$ cells that eventually halted the growth of these cells (Fig. 8). These results are consistent with previous studies, demonstrating that curcumin by itself, has the potential to alter cyclin D1 and p21 expression and in combination with common chemotherapeutic drugs, the inhibitory effects were enhanced 
through the inhibition of CSCs $(70,71)$. Although we noted that the combination treatment enhanced mRNA expression of Apaf1 and caspase-9 in the CSC subpopulation of A549 cells, compared to cisplatin treatment alone, the combination treatment did not influence Apaf 1 and caspase-9 expression in the CSC subpopulation of $\mathrm{H} 2170$ cells. We believed that this is due to the heterogeneity of CSCs that leads to the different sensitivity of the double-positive $\left(\mathrm{CD} 166^{+} / \mathrm{EpCAM}^{+}\right)$subpopulation to the treatment outcome.

In conclusion, we showed that curcumin is able to increase the efficacy of low dose cisplatin in unsorted NSCLC cell lines. Through our investigation of the sorted NSCLC cell lines, we also found that curcumin had the capacity to enhance cisplatin-induced metastatic inhibition and apoptosis of the highly migratory CSC subpopulation $\left(\mathrm{CD} 166^{+} / \mathrm{EpCAM}^{+}\right)$ in the NSCLC cell lines suggesting that curcumin might be useful as a complement to common chemotherapy for inhibiting tumour progression and reducing metastasis.

\section{Acknowledgements}

The authors wish to thank the Director General of Health, Malaysia for his permission to publish this paper. This study was supported by a Ministry of Health grant, JPP-IMR-12-023.

\section{References}

1. Siegel R, Naishadham D and Jemal A: Cancer statistics, 2012. CA Cancer J Clin 62: 10-29, 2012.

2. Jemal A, Bray F, Center MM, Ferlay J, Ward E and Forman D: Global cancer statistics. CA Cancer J Clin 61: 69-90, 2011.

3. Hanahan D and Weinberg RA: The hallmarks of cancer. Cell 100: 57-70, 2000.

4. Mountain CF, Lukeman JM, Hammar SP, Chamberlain DW, Coulson WF, Page DL, Victor TA and Weiland LH: Lung cancer classification: The relationship of disease extent and cell type to survival in a clinical trials population. J Surg Oncol 35: 147-156, 1987.

5. Curtis SJ, Sinkevicius KW, Li D, Lau AN, Roach RR,Zamponi R, Woolfenden AE, Kirsch DG, Wong K-K and Kim CF: Primary tumor genotype is an important determinant in identification of lung cancer propagating cells. Cell Stem Cell 7: 127-133, 2010.

6. Tan BT, Park CY, Ailles LE and Weissman IL: The cancer stem cell hypothesis: A work in progress. Lab Invest 86: 1203-1207, 2006.

7. Gil J, Stembalska A, Pesz KA and Sasiadek MM: Cancer stem cells: The theory and perspectives in cancer therapy. J Appl Genet 49: 193-199, 2008.

8. Li L and Neaves WB: Normal stem cells and cancer stem cells: The niche matters. Cancer Res 66: 4553-4557, 2006.

9. Mukherjee S, Kong J and Brat DJ: Cancer stem cell division: When the rules of asymmetry are broken. Stem Cells Dev 24: 405-416, 2015.

10. Chen S and Huang EH: The colon cancer stem cell microenvironment holds keys to future cancer therapy. J Gastrointest Surg 18: 1040-1048, 2014.

11. O'Flaherty JD, Barr M, Fennell D, Richard D, Reynolds J, O'Leary J and O'Byrne K: The cancer stem-cell hypothesis: Its emerging role in lung cancer biology and its relevance for future therapy. J Thorac Oncol 7: 1880-1890, 2012.

12. Hong IS, Lee HY and Nam JS: Cancer stem cells: The 'Achilles heel' of chemo-resistant tumors. Recent Patents Anticancer Drug Discov 10: 2-22, 2015.

13. Orian-Rousseau V and Ponta H: Perspectives of CD44 targeting therapies. Arch Toxicol 89: 3-14, 2015.

14. Ma J, Fang B, Zeng F, Pang H, Zhang J, Shi Y, Wu X, Cheng L, Ma C, Xia J, et al: Curcumin inhibits cell growth and invasion through up-regulation of miR-7 in pancreatic cancer cells. Toxicol Lett 231: 82-91, 2014.
15. Mukherjee S, Mazumdar M, Chakraborty S, Manna A, Saha S, Khan P, Bhattacharjee P, Guha D, Adhikary A, Mukhjerjee $\mathrm{S}$, et al: Curcumin inhibits breast cancer stem cell migration by amplifying the E-cadherin $/ \beta$-catenin negative feedback loop. Stem Cell Res Ther 5: 116, 2014.

16. Sarkar R, Mukherjee A, Mukherjee S, Biswas R, Biswas J and Roy M: Curcumin augments the efficacy of antitumor drugs used in leukemia by modulation of heat shock proteins via HDAC6. Environ Pathol Toxicol Oncol 33: 247-263, 2014.

17. Xiao C, Wang L, Zhu L, Zhang C and Zhou J: Curcumin inhibits oral squamous cell carcinoma SCC-9 cells proliferation by regulating miR-9 expression. Biochem Biophys Res Commun 454: 576-580, 2014

18. Ye M, Zhang J, Zhang J, Miao Q, Yao L and Zhang J: Curcumin promotes apoptosis by activating the $\mathrm{p} 53-\mathrm{miR}-192-5 \mathrm{p} / 215-\mathrm{XIAP}$ pathway in non-small cell lung cancer. Cancer Lett 357: 196-205, 2015.

19. Anand P, Sundaram C, Jhurani S, Kunnumakkara AB and Aggarwal BB: Curcumin and cancer: An 'old-age' disease with an 'age-old' solution. Cancer Lett 267: 133-164, 2008.

20. Andjelkovic T, Pesic M, Bankovic J, Tanic N, Markovic ID and Ruzdijic S: Synergistic effects of the purine analog sulfinosine and curcumin on the multidrug resistant human non-small cell lung carcinoma cell line (NCI-H460/R). Cancer Biol Ther 7: 1024-1032, 2008.

21. Ebert B, Seidel A and Lampen A: Phytochemicals induce breast cancer resistance protein in Caco-2 cells and enhance the transport of benzo(a)pyrene-3-sulfate. Toxicol Sci 96: 227-236, 2007.

22. Hou X-L, Takahashi K, Tanaka K, Tougou K, Qiu F, Komatsu K, Takahashi K and Azuma J: Curcuma drugs and curcumin regulate the expression and function of P-gp in Caco-2 cells in completely opposite ways. Int J Pharm 358: 224-229, 2008.

23. Chanvorachote $P$, Pongrakhananon V, Wannachaiyasit $S$, Luanpitpong S, Rojanasakul Y and Nimmannit U: Curcumin sensitizes lung cancer cells to cisplatin-induced apoptosis through superoxide anion-mediated Bcl-2 degradation. Cancer Invest 27: 624-635, 2009.

24. Li S, Liu Z, Zhu F, Fan X, Wu X, Zhao H and Jiang L: Curcumin lowers erlotinib resistance in non-small cell lung carcinoma cells with mutated EGF receptor. Oncol Res 21: 137-144, 2013.

25. Chan MM, Fong D, Soprano KJ, Holmes WF and Heverling H: Inhibition of growth and sensitization to cisplatin-mediated killing of ovarian cancer cells by polyphenolic chemopreventive agents. J Cell Physiol 194: 63-70, 2003.

26. Chan MM, Soprano KJ, Weinstein K and Fong D: Epigallo catechin-3-gallate delivers hydrogen peroxide to induce death of ovarian cancer cells and enhances their cisplatin susceptibility. J Cell Physiol 207: 389-396, 2006.

27. Duarte VM, Han E, Veena MS, Salvado A, Suh JD, Liang LJ, Faull KF, Srivatsan ES and Wang MB: Curcumin enhances the effect of cisplatin in suppression of head and neck squamous cell carcinoma via inhibition of IKK $\beta$ protein of the NFKB pathway. Mol Cancer Ther 9: 2665-2675, 2010.

28. Notarbartolo M, Poma P, Perri D, Dusonchet L, Cervello M and D'Alessandro N: Antitumor effects of curcumin, alone or in combination with cisplatin or doxorubicin, on human hepatic cancer cells. Analysis of their possible relationship to changes in NF- $\kappa \mathrm{B}$ activation levels and in IAP gene expression. Cancer Lett 224: 53-65, 2005.

29. Aggarwal BB, Shishodia S, Takada Y, Banerjee S, Newman RA, Bueso-Ramos CE, Price JE: Curcumin suppresses the paclitaxel-induced nuclear factor-kappaB pathway in breast cancer cells and inhibits lung metastasis of human breast cancer in nude mice. Clin Cancer Res 11: 7490-7498, 2005.

30. Cheng AL, Hsu CH, Lin JK, Hsu MM, Ho YF, Shen TS, Ko JY, Lin JT, Lin BR, Ming-Shiang W, et al: Phase I clinical trial of curcumin, a chemopreventive agent, in patients with high-risk or pre-malignant lesions. Anticancer Res 21: 2895-2900, 2001.

31. Ginestier C, Hur MH, Charafe-Jauffret E, Monville F, Dutcher J, Brown M, Jacquemier J, Viens P, Kleer CG, Liu S, et al: ALDH1 is a marker of normal and malignant human mammary stem cells and a predictor of poor clinical outcome. Cell Stem Cell 1: 555-567, 2007.

32. Kakarala M, Brenner DE, Korkaya H, Cheng C, Tazi K, Ginestier C, Liu S, Dontu G and Wicha MS: Targeting breast stem cells with the cancer preventive compounds curcumin and piperine. Breast Cancer Res Treat 122: 777-785, 2010. 
33. Fong D, Yeh A, Naftalovich R, Choi TH and Chan MM: Curcumin inhibits the side population (SP) phenotype of the rat C6 glioma cell line: Towards targeting of cancer stem cells with phytochemicals. Cancer Lett 293: 65-72, 2010.

34. Zhuang W, Long L, Zheng B, Ji W, Yang N, Zhang Q and Liang Z: Curcumin promotes differentiation of glioma-initiating cells by inducing autophagy. Cancer Sci 103: 684-690, 2012.

35. Pellacani D, Oldridge EE, Collins AT and Maitland NJ: Prominin-1 (CD133) expression in the prostate and prostate cancer: A marker for quiescent stem cells. Adv Exp Med Biol 777: 167-184, 2013

36. Reyes EE,Kunovac SK,Duggan R, Kregel S and Vander Griend DJ Growth kinetics of CD133-positive prostate cancer cells. Prostate 73: 724-733, 2013

37. Vander Griend DJ, Karthaus WL, Dalrymple S, Meeker A, DeMarzo AM and Isaacs JT: The role of CD133 in normal human prostate stem cells and malignant cancer-initiating cells. Cancer Res 68: 9703-9711, 2008.

38. Bi CL, Fang JS, Chen FH, Wang YJ and Wu J: Chemoresistance of CD133(+) tumor stem cells from human brain glioma. Zhong Nan Da Xue Xue Bao Yi Xue Ban 32: 568-573, 2007 (In Chinese).

39. Choi SA, Wang KC, Phi JH, Lee JY, Park CK, Park SH and Kim SK: A distinct subpopulation within CD133 positive brain tumor cells shares characteristics with endothelial progenitor cells. Cancer Lett 324: 221-230, 2012.

40. Li MC, Deng YW, Wu J, Chen FH, Liu JF and Fang JS: Isolation and characterization of brain tumor stem cells in human medulloblastoma. Ai Zheng 25: 241-246, 2006 (In Chinese).

41. Singh S and Dirks PB: Brain tumor stem cells: Identification and concepts. Neurosurg Clin N Am 18: 31-38, 2007.

42. Kozovska Z, Gabrisova V and Kucerova L: Colon cancer: Cancer stem cells markers, drug resistance and treatment. Biomed Pharmacother 68: 911-916, 2014

43. Mărgaritescu C, Pirici D, Cherciu I, Bărbălan A, Cârtână T and Săftoiu A: CD133/CD166/Ki-67 triple immunofluorescence assessment for putative cancer stem cells in colon carcinoma. J Gastrointestin Liver Dis 23: 161-170, 2014

44. Vincent Z, Urakami K, Maruyama K, Yamaguchi K and Kusuhara M: CD133-positive cancer stem cells from Colo205 human colon adenocarcinoma cell line show resistance to chemotherapy and display a specific metabolomic profile. Genes Cancer 5: 250-260, 2014

45. Cogliati B,Aloia TP,Bosch RV, Alves VA,Hernandez-Blazquez FJ and Dagli ML: Identification of hepatic stem/progenitor cells in canine hepatocellular and cholangiocellular carcinoma. Vet Comp Oncol 8: 112-121, 2010.

46. Tomuleasa C, Soritau O, Rus-Ciuca D, Pop T, Todea D, Mosteanu O, Pintea B, Foris V, Susman S, Kacsó G, et al: Isolation and characterization of hepatic cancer cells with stem-like properties from hepatocellular carcinoma. J Gastrointestin Liver Dis 19: 61-67, 2010.

47. Yang XR, Xu Y, Yu B, Zhou J, Qiu SJ, Shi GM, Zhang BH, Wu WZ, Shi YH, Wu B, et al: High expression levels of putative hepatic stem/progenitor cell biomarkers related to tumour angiogenesis and poor prognosis of hepatocellular carcinoma. Gut 59: 953-962, 2010

48. Zhang L, Sun H, Zhao F, Lu P, Ge C, Li H, Hou H, Yan M, Chen T, Jiang G, et al: BMP4 administration induces differentiation of $\mathrm{CD} 33^{+}$hepatic cancer stem cells, blocking their contributions to hepatocellular carcinoma. Cancer Res 72: 4276-4285, 2012.

49. Bertolini G, Roz L, Perego P, Tortoreto M, Fontanella E, Gatti L, Pratesi G, Fabbri A, Andriani F, Tinelli S, et al: Highly tumorigenic lung cancer $\mathrm{CD} 133^{+}$cells display stem-like features and are spared by cisplatin treatment. Proc Natl Acad Sci USA 106 16281-16286, 2009.

50. Salnikov AV, Gladkich J, Moldenhauer G, Volm M, Mattern J and Herr I: CD133 is indicative for a resistance phenotype but does not represent a prognostic marker for survival of non-small cell lung cancer patients. Int J Cancer 126: 950-958, 2010

51. Sullivan JP, Spinola M, Dodge M, Raso MG, Behrens C, Gao B, Schuster K, Shao C, Larsen JE, Sullivan LA, et al: Aldehyde dehydrogenase activity selects for lung adenocarcinoma stem cells dependent on notch signaling. Cancer Res 70: 9937-9948, 2010.

52. Woo T, Okudela K, Mitsui H, Yazawa T, Ogawa N, Tajiri M, Yamamoto T, Rino Y, Kitamura $\mathrm{H}$ and Masuda M: Prognostic value of CD133 expression in stage I lung adenocarcinomas. Int J Clin Exp Pathol 4: 32-42, 2010.
53. Sterlacci W, Savic S, Fiegl M, Obermann E and Tzankov A: Putative stem cell markers in non-small-cell lung cancer: A clinicopathologic characterization. J Thorac Oncol 9: 41-49, 2014.

54. Zhang WC, Shyh-Chang N, Yang H, Rai A, Umashankar S, Ma S, Soh BS, Sun LL, Tai BC, Nga ME, et al: Glycine decarboxylase activity drives non-small cell lung cancer tumor-initiating cells and tumorigenesis. Cell 148: 259-272, 2012.

55. Zakaria N, Yusoff NM, Zakaria Z, Lim MN, Baharuddin PJN, Fakiruddin KS and Yahaya B: Human non-small cell lung cancer expresses putative cancer stem cell markers and exhibits the transcriptomic profile of multipotent cells. BMC Cancer 15: 84, 2015.

56. Chen K, Huang YH and Chen JL: Understanding and targeting cancer stem cells: Therapeutic implications and challenges. Acta Pharmacol Sin 34: 732-740, 2013.

57. Xu X-M, Zhang Y, Qu D, Liu H-B, Gu X, Jiao G-Y and Zhao L: Combined anticancer activity of osthole and cisplatin in NCI-H460 lung cancer cells in vitro. Exp Ther Med 5: 707-710, 2013.

58. Douillard J-Y, Eckardt J and Scagliotti GV: Challenging the platinum combinations in the chemotherapy of NSCLC. Lung Cancer 38 (Suppl 4): 21-28, 2002.

59. Stewart DJ: Mechanisms of resistance to cisplatin and carboplatin. Crit Rev Oncol Hematol 63: 12-31, 2007.

60. Burnett J, Newman B and Sun D: Targeting cancer stem cells with natural products. Curr Drug Targets 13: 1054-1064, 2012.

61. Mondal S, Bandyopadhyay S, Ghosh MK, Mukhopadhyay S, Roy S and Mandal C: Natural products: Promising resources for cancer drug discovery. Anticancer Agents Med Chem 12: 49-75, 2012.

62. Ye MX, Zhao YL, Li Y, Miao Q, Li ZK, Ren XL, Song LQ, Yin $\mathrm{H}$ and Zhang J: Curcumin reverses cis-platin resistance and promotes human lung adenocarcinoma A549/DDP cell apoptosis through HIF-1alpha and caspase-3 mechanisms. Phytomedicine 19: 779-787, 2012.

63. Zhou B-BS, Zhang H, Damelin M, Geles KG, Grindley JC and Dirks PB: Tumour-initiating cells: Challenges and opportunities for anticancer drug discovery. Nat Rev Drug Discov 8: 806-823, 2009.

64. Buhrmann C, Kraehe P, Lueders C, Shayan P, Goel A and Shakibaei M: Curcumin suppresses crosstalk between colon cancer stem cells and stromal fibroblasts in the tumor microenvironment: Potential role of EMT. PLoS One 9: e107514, 2014.

65. Charpentier MS, Whipple RA, Vitolo MI, Boggs AE, Slovic J, Thompson KN, Bhandary L and Martin SS: Curcumin targets breast cancer stem-like cells with microtentacles that persist in mammospheres and promote reattachment. Cancer Res 74: 1250-1260, 2014

66. Wang X, Zhu Y, Ma Y, Wang J, Zhang F, Xia Q and Fu D: The role of cancer stem cells in cancer metastasis: New perspective and progress. Cancer Epidemiol 37: 60-63, 2013.

67. Fazilaty H, Gardaneh M, Bahrami T, Salmaninejad A and Behnam B: Crosstalk between breast cancer stem cells and metastatic niche: Emerging molecular metastasis pathway? Tumour Biol 34: 2019-2030, 2013

68. Croker AK, Goodale D, Chu J, Postenka C, Hedley BD, Hess DA and Allan AL: High aldehyde dehydrogenase and expression of cancer stem cell markers selects for breast cancer cells with enhanced malignant and metastatic ability. J Cell Mol Med 13: 2236-2252, 2009

69. Hermann PC, Huber SL, Herrler T, Aicher A, Ellwart JW, Guba M, Bruns CJ and Heeschen C: Distinct populations of cancer stem cells determine tumor growth and metastatic activity in human pancreatic cancer. Cell Stem Cell 1: 313-323, 2007.

70. Srivastava RK, Chen Q, Siddiqui I, Sarva K and Shankar S: Linkage of curcumin-induced cell cycle arrest and apoptosis by cyclin-dependent kinase inhibitor p21(/WAF1/CIP1). Cell Cycle 6: 2953-2961, 2007.

71. Zhang H, Yu T, Wen L, Wang H, Fei D and Jin C: Curcumin enhances the effectiveness of cisplatin by suppressing CD133(+) cancer stem cells in laryngeal carcinoma treatment. Exp Ther Med 6: 1317-1321, 2013. 